systemic infections by vaccine therapy is indicated.

With regard to pernicious anæmia, time will not permit of the discussion that the subject deserves, but the essential features in the blood are a lowered erythrocyte count, a colour index of $I^{\prime} O$ or over, an increase in the average size of the red cells, with presence of embryonic erythroblasts of the type peculiar to this disease. These cells are easily recognized by an experienced observer and are similar to those found in the islets of Pander on the walls of the yolk sac of the embryo, and in fotal liver. They are quile distinct from the normoblasts and macronormoblasts present in the bone marrow, though these latter may be and often are present also in pernicious anæmia. Leucopenia is markedly present, with a relative lymphocytosis.

In secondary anæmia, on the other hand, while the total red cell count may be diminished, and always is in severe cases, especially those due to hæmorrhage, normoblasts and macronormoblasts may be present, but the embryonic erythroblasts are absent, the colour index is lowered to 0.6 or less and the average size of the red cells is not increased. Carcinoma generally gives rise to the blood-picture of septic infection.

Inequality in size and shape of the red cells is found both in pernicious anæmia and severe cases of secondary anæmia due to hæmorrhage or sepsis.

The rare condition known as aplastic anæmia should be mentioned here. The features are a marked diminution in the number of all the cells, with absence of primitive forms, the differential count usually showing no histological abnormality. It is sometimes seen as the terminal stage of sepsis or hæmorrhage, but it is more often a primary disease, the exact causation of which is at present unknown. It is sometimes due to excessive doses of $\mathrm{X}$-ray or radium.

(d) The Leukamic group. Here there is no difficulty in diagnosis if the blood be examined. There is a large increase in the total and relative number of the granular cells in the spieno-medullary type, and of the lymphocytes in the lymphatic variety, with a shift towards primitive forms, which becomes more prominent as the disease progresses.

This is often so marked that in the terminal stage it is sometimes difficult to say whether the disease was originally myeloid or lymphatic, the blood-picture consisting almost entirely of ancestors of both forms.

(e) The Purpura group.-Here we have hæmorrhages into or underneath the skin, with bleeding from mucous membranes or internal organs. The two main causes of this are platelet deficiency and bacterial infection. In the former group (essential thrombocytopenia hæmorrhagica) the platelets are reduced to 50,000 per c.mm. or may even be practically absent, so that only two or three are seen in a whole slide. The importance of this observation lies in the fact that splenectomy is usually the only successful treatment whereas, in bacterial infection, the operation is almost always fatal and is contra-indicated.

The lecture was illustrated by drawings of the cells referred to and by diagrams and charts showing the various methods of blood formation.

\section{A LECTURE ON CRIME AND INSANITY.}

GIVEN AT THE MAUDSLEy hospital, APRIL 30, 1929.

\section{By W. NORWOOD EAST, \\ M.D., M.R.C.P.}

Medical Inspector, H.M. Prisons, England and Wales

THE association of crime with mental deficiency or insanity may become a matter of importance to the family physician as well as to the alienist, for both may be consulted 
by the relations or friends of an accused person for the purpose of his defence. And although the medical attendant may be unskilled in psychiatry, his considered opinion may be especially valuable if he can testify from personal observation that the conduct and character of the defendant underwent material alteration prior to the commission of the offence, or that definite symptoms of mental disorder were then declared.

Again, if the symptoms of mental disorder are transitory, as may be the case in alcoholic, epileptic, confusional and mild psychotic attacks, the observations of the family practitioner may usefully support the opinion of the psychiatrist, particularly if the symptoms have been recovered from before the latter is consulted. Without the assistance of his colleague the alienist may be obliged to make deductions from the hearsay statements of well-meaning but technically ignorant laymen.

The medical observer should discard any preconceived opinion that crime itself is evidence of mental abnormality, or that the criminal is necessarily a social and atavistic anomaly, for neither can be supported by unbiased observation and research. $\mathrm{He}$ may usefully reflect that the normal in any community is a composite abstraction made up from the average variations presented by the society from which the subject is taken, and that there is no clear line of demarcation between the psychological normal and abnormal. The normal reaction to a stimulus in Bermondsey may be abnormal in Mayfair. It should be remembered that the criminal is the man in the street and that we are all potential criminals, although our self-esteem prevents a general acceptance of this view. Criminal conduct is the objective expression of a subjective mental state, which cannot be considered abnormal until all the surrounding circumstances have been reviewed as well as the mental condition of the accused. The causes of any criminal act or prolonged course of criminal conduct are seldom simple; heredity, environment, past associations, experiences and impressions, and the physical and mental condition of the offender require exploration before the various factors can be assessed.

It is my purpose in these lectures to deal with the subject of crime and insanity from the practical point of view, and to consider the problems which are most likely to arise during the course of a criminal trial in which the mental condition of the accused is in dispute. The actions of the majority of offenders admit of ordinary explanations $\vec{v}$ which may be obscured and overlooked by $\overrightarrow{\vec{\infty}}$ those who are attracted by involved and speculative interpretations. Nevertheless, $\stackrel{5}{\rightarrow}$ there are cases in which psychological $\vec{P}$ conceptions offer some explanation of conduct otherwise unintelligible, and it $\stackrel{9}{9}$ would seem that they may form steppings $\overrightarrow{0}$ stones towards future understanding if the fallacies connected therewith, and the opposing views of different schools of psychological thought are appreciated.

The main causes of human conduct are believed by marry to lie in the inherited $\stackrel{2}{\vec{P}}$ instincts and their accompanying emotions. In criminal work instinctive activity is often found to be excessive or insufficient for social adjustments. A strong acquisitive instinct may result in theft, and the mental examinations of young unmarried women indicate that sometimes a weak maternalo̊ instinct may result in infanticide when opposed by a strong self-preservative instinct. Faulty control and crime may result if the emotional accompaniment of instinctive action fails to become inhibited by con -5 siderations of the probable consequences, and if action is directed by desire instead of reason.

Crime is described in legal textbooks as "an act or omission forbidden by law under ${ }^{?}$ pain of punishment," and moral turpitude $\frac{0}{0}$ is not an essential ingredient nor marked ${ }_{0}^{\circ}$ social disapproval a necessary sequel. Motor $\frac{0}{0}$ car legislation and prohibition laws cause Q 
many socially acceptable individuals to commit crime, and demonstrate the potential criminality which exists in even highly organized communities. Crime is fundamentally conduct which is considered to be injurious to the society to which the offender belongs, and may be described psychologically as the replacement of social behaviour by self-regarding behaviour.

Some idea of the importance of the problem of the association of crime and insanity or mental deficiency can be deduced from official statistics. The Prison Commissioners state in their annual report for I927 that among convicted prisoners in England and Wales 9I men and 8 women were certified insane during the year. In addition 189 men and 48 women were found to be insane whilst on remand, and 42 men and 17 women were found to be insane by juries :-2 I men and 7 women were found to be insane on arraignment, and $2 \mathrm{r}$ men and Io women guilty but insane. During the same period 148 males and 20 females were reported to the courts to be certifiable under the Mental Deficiency Acts and were dealt with under section 8 of the Act of I9r3. In addition 65 males and in females were certified under section 9 of the same Act during their imprisonment. A total of 639 delinquents were dealt with under the Lunacy and Mental Deficiency Acts. There were also some 2,000 prisoners remanded to prison from the courts for mental observation, and reports upon their mental conditions were forwarded to the justices by the medical officers at the expiration of the remand period.

The above figures exclude a considerable number of borderline cases, whose mental condition was not sufficiently abnormal to sanction legal detention.

It is generally admitted that a defence of insanity is most frequently raised in cases of murder, and the Criminal Statistics of England and Wales for the year 1927 record that 140 persons were known to the police to have been murdered during that year ; $4 \mathrm{I}$ were infants up to I year in age; 99 were of various ages from I year upwards, 36 being males and 63 females. As regards the infants up to I year no arrests were made in 28 cases, of which 26 were newly-born children. Of the other 13 infants two of the murderers committed suicide and II were arrested, all of them women or girls. One of the women, who was also charged with the murder of another child over. I year old, was certified as insane before trial. Of the Io other women, 3 were discharged at the Police Court, 5 were found to be insane, and 2 were sentenced to death and the sentence commuted to penal servitude for life.

The murders of the 99 persons of various ages from I year upwards included I case in which 4 persons were murdered, 2 in which 3 persons were murdered, and 5 in which 2 persons were murdered.

As regards the murders of these 990 persons, $4 \mathrm{r}$ murderers committed suicide, I suspect died in an asylum without proceedings being taken, and $5^{\mathrm{I}}$ arrests were made. Of the $4 \mathrm{r}$ murderers who committed suicide, I had killed 4 persons, I had killed 3 persons, and 3 had each killed 2 persons.

Of the $5 \mathrm{I}$ persons who were arrested $\mathrm{I}$ was arrested for killing 3 persons, 2 for each killing 2. On the other hand the murder of I person resulted in five arrests, and in each two cases of murder of I person 2 persons were arrested.

Three persons arrested and charged with murder in cases where deaths were due to illegal operations were acquitted. The results of the proceedings against the other 48 persons who were arrested for the murders of persons of various ages from I year upwards were as follows: six were acquitted and 20 were found to be insane. Of the remaining 22 the sentence of death was executed in 19 cases, and in 3 the death sentence was commuted to penal servitude for life. Briefly, in the cases of 99 persons of I year upwards who were murdered, $4 \mathrm{I}$ murderers committed suicide, and of $5 \mathrm{I}$ 
arrests 20 murderers were found to be insane.

The investigation into the mental condition of an accused person requires much time. The examination should never be hurried. The excited hostile or negativistic attitude of the subject may necessarily postpone the examination until a more opportune moment. In favourable circumstances an interview of two hours' duration approximates the period which may be spent profitably in the investigation at any one sitting, as fatigue on the part of the subject and the examiner must be avoided to ensure reliable results. An exception is sometimes advisable in cases of paranoia as the examiner will usually become fatigued before the patient, who may be anxious to discuss his delusions freely then, but refuse to do so at a future sitting if his suspicions are aroused.

Two or more examinations of an accused person are desirable. It is useful to look upon the first as a preliminary introduction to the subject, and it is an advantage for the examiner to make himself acquainted beforehand with all the known circumstances of the crime. Subsequent examinations may eliminate previous doubts, expose discrepancies in the statement of a malingerer, or corroborate previous statements if true.

Since there are no medical secrets in a criminal court, and the medical witness cannot claim privilege for confidences disclosed to him by a prisoner, it is always advisable to give some form of caution at the beginning of the interview. Otherwise the legal representative of the prisoner may adversely criticize the witness. When medical men are asked to examine a prisoner for his defence they usually tell him at whose request they act. An official medical officer does not know whether his evidence will be of importance to the prosecution or defence until his examination is completed. But it is always desirable to inform the prisoner that the interview is held for the purpose of inquiring into his mental con- dition, and that he is under no obligation to answer anything unless he is willing to do $\stackrel{c}{c}$ so. This would appear to be an adequate $\overrightarrow{\vec{s}}$ caution, as it was quoted in court during a murder case, and was not criticized by the judge or by the defending counsel.

The medical examiner is entitled to note $\stackrel{\mathbb{Q}}{\varrho}$ anything that the prisoner may say in connection with the crime and the part he took $\overrightarrow{0}$ in it. It is permissible to ask him questions $\overrightarrow{\vec{\omega}}$ arising out of those statements, but he must $\stackrel{\omega}{\sigma}$ carefully avoid asking the prisoner whether $\overline{0}$ he committed the crime, nor may he put leading questions which assume the crime was committed by him. Full notes should be taken at the interview; they may be $\stackrel{\infty}{v}$ referred to in the witness box if they were $\frac{\text { ? }}{2}$ made at the time of the examination, or as $\vec{P}$ soon after as possible.

All the known circumstances of the crime $\frac{0}{9}$ should be carefully reviewed and criticized $\overrightarrow{0}$ in the light of the mental condition of the accused, and with the knowledge that the insane may act sanely, and that the action of a sane man may appear insane unless the examiner is acquainted with the relevant circumstances. The ascertainment of mental disease or defect in an alleged criminal demands a correct interpretation of symptoms or events, alleged or proved, a meticulous attention to details, and an impartial balancing of what is or may be normal against what is or may be abnormal.

It is a matter of common knowledge that the motives and temptations which are sufficient to provoke crime by certain 웅 individuals have no such effect on others, $\frac{7}{0}$ and it is sometimes suggested that this is an indication of mental disorder; for N example, in cases where a person commits $\tilde{O}$ murder for a small sum of money. But $\underset{\omega}{N}$ before a crime of this character can be considered abnormal, at least two matters $\stackrel{0}{\sim}$ require careful investigation: the inquirer $\stackrel{\mathbb{Q}}{\rightarrow}$ must be satisfied first that he is in possession 0 of the full circumstances relating to the $\stackrel{\circ}{\circ}$ crime, and that every avenue has been $\stackrel{\mathbb{Q}}{\mathbb{D}}$ explored which may throw light upon the $\frac{\mathbb{Q}}{0}$ 
intention of the offender ; and secondly he must be satisfied, as a result of his experience in similar cases, that the crime is outside the limits of the ordinary reactions of persons of the same class and upbringing as the accused when subjected to similar motives and temptations.

The motive and intention of a criminal act are frequently under consideration in the courts of law, and occasionally cause some confusion among medical witnesses. It may be useful to bear in mind that motive is the reason for a particular course of action, and that intention is the desire to produce a particular result. Sir James Fitzjames Stephen illustrated the difference thus : A puts a loaded pistol to B's temple and shoots $B$ through the head deliberately, and knowing the pistol is loaded and that the wound must certainly be mortal. It is obvious that in every such case the intention of A must be to kill B. But it throws no light on A's motive for killing $B$. It may have been for revenge, for plunder, or to defend himself against attack from $B$. In each case the intention is the same, but the motive is different.

The assumed motive for a crime may be misleading in cases of so-called substitution crime. Thus a man committed an apparently motiveless murder which was ultimately shown to have resulted from a desire to be hanged as the homicide considered suicide was wrong. In one case a man committed burglary to possess himselt of female underclothing to satisfy a sex fetichism. In another case a shoefetichist committed burglary in order to obtain shoes. In another a man committed arson so that he could receive a long sentence of penal servitude and so escape the temptation to commit homo-sexual olfences. The motive for the crime of an insane or defective person may be reasonable and adequate, but in many who cannot be dealt with as defective or insane the motive or temptation would be inadequate for the majority of ordinary individuals.
During the examination inquiry should be made concerning the activity of the instincts, emotions, and inhibitory capacity of the accused, and they should be regarded in the light which may be thrown upon them by the history of the offender, and the circumstances of the crime. Memory, attention, perception and recognition can be assessed with some accuracy as a result of the examination. Evidence of a psychosis or neurosis must be looked for, and the offender's demeanour and conversation at the interview should be compared with his conduct at the time of the crime. It must also be remembered that some people when interviewed appear more alert and responsive for a short time than they really are, and others fail to do themselves justice.

In cases in which mental deficiency is suspected intelligence tests should be applied, and, since they occupy considerable time, and require the subject's attention, they should be conducted in the early part of the examination. It must be observed, however, in connection with these tests that the ultimate criterion of mental deficiency in criminal adolescents is the capacity for social adaptability, and not merely an educational standard, which may depend upon a plurality of influences unconnected with amentia. Intelligence tests are of particular value to the medical witness when he endeavours to explain degrees of mental deficiency in court. The tests appear to be more useful in assessing the mental age of an accused person than in the investigation of some particular mental function. It is probably more important to use many tests than fewer and longer ones, and during the application and throughout the interview it is necessary for the examiner to be constantly on the alert for indications of fatigue, and to guard against emotional disturbances which imay affect the findings.

It is most important to assess the moral and temperamental disabilities of persons accused of crime, but, unfortunately, experimental tests are not at present of 
material assistance in this direction. For this purpose skilled unbiased observation and deductions from ascertained facts must be relied upon.

The diagnosis of insanity and mental deficiency in persons who have committed a criminal offence is liable to become obscured by malingering. And it is not always recognized that the insane sometimes seek this refuge from the consequences of their acts, and assume insane symptoms in ignorance of their mental disorder. A man who was depressed and deluded left his bed one night, accusing his wife of being against him. He went to a medicine cupboard saying he wished to find some poison. He returned to bed and immediately attacked his wife with a razor. She was severely injured, but escaped from the room. He then cut his own throat, opening the trachea. His wife stated that he got up at night and looked out of the window to detect the owners of the imaginary voices which he heard abusing him, and stamped about the room to let his persecutors know that he was awake and ready to repel any attack from them. He said that he remembered all the events connected with the crime except the attack on his wife, and when told that he could not expect me to to believe that the only facts he forgot were the material ones connected with the charge, he smiled and said that if he admitted any recollection of wounding his wife he would convict himself. $\mathrm{He}$ had no insight into his mental condition and assumed a loss of memory as a pathological defence.

On the other hand, the insane sometimes malinger sanity to effect the punishment prescribed by their delusions, or to escape from them. A homicide refused to discuss his delusions for a long time: He said that if he disclosed the manner in which he had been persecuted it would be alleged he suffered from delusions, and he would be sent to Broadmoor, but he wished to be hanged and so gain peace. Other factors which render the diagnosis difficult at times are the artefacts which the medical investigation produces in a cunning prisoner. And further, the tact and sympathy of the examiner may be insufficient to disarm the hostility which is occasionally a sequel to arrest.

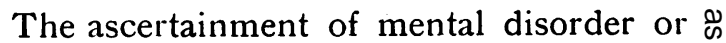
defect may be materially assisted by an $\overrightarrow{0}$ inspection of previous photographs of the accused. It is only necessary to recall the facies which may be associated with imbecility, dementia, general paralysis, depressed, anxiety and delusional states to indicate the possible use of a photograph in comparing the present mental condition of an accused person with that of his past.

An inspection of the letters written by an offender may assist the diagnosis. They may refer to delusions the patient will not discuss, they may express his emotional tone, words or letters may be omitted sugo ç gesting general paralysis of the insane, and senile writing may suggest dementia. It two difficult cases with which I was concerned mirror writing was of material assistance in the diagnosis.

Errors may arise if the truth regarding the physical and psychological events connected with a crime are inaccessible, as for example when two persons only are present, the murderer and his victim. Moreover, the unbecoming actions of everyday life may be attributed to worthy motives as the result of rationalization, and the psychological events associated with a crime may be 9 obscured by the same process.

Further, the most spontaneous and common excuse made by an accused per- N son is that he has no recollection of the $\tilde{O}$ material acts connected with the crime. Patient investigation is necessary to ascertain the truth or falsity of this statement. But it should be remembered that if a partial $\stackrel{\oplus}{\rightarrow}$ amnesia for the events of a crime is alleged at the first interview, and the accused subsequently appears to remember more than he $\frac{\Omega}{\mathbb{D}}$ originally admitted, it may be due to his $\frac{0}{9}$ 
memory becoming refreshed by what he may have heard discussed in later appearances at court, by friends, or by what he has read in the press. At the same time it must not be forgotten that the astute malingerer may claim this to be so when he appreciates that the discrepancies between his earlier and later recollections have been observed.

In certain circumstances it appears possible that if the execution of a crime results in more serious consequences to the victim than was intended by the criminal, the consequent emotional shock to the latter may result in a genuine dissociation and true amnesia:

The influence of an insane heredity is frequently raised at a criminal trial, and in many cases of murder a family history of insanity is submitted, and may be the only reason to suggest that the prisoner is himself insane. It is important that any information relating to familial insanity should be pursued and corroborated if possible. When the law is strictly applied proof of insanity is required from witnesses who can be examined, and it may be necessary to produce the registers of mental hospitals for the purpose.

The importance of heredity in transmitting tendencies to mental instabilities is undisputed. Pedigrees of insane patients have been demonstrated which show considerably more insanity than mental deficiency among the relatives, and conversely mental deficiency to be more prevalent than insanity in the families of mentally defective children, and the general level of intelligence and health among the brothers and sisters of special school children to be distinctly below that of normal children.' The conclusions of Maudsley, that a person does not inherit insanity, but a predisposition which may appear as insanity, allied nervous disorder, feeblemindedness, or various eccentricities, may be remembered profitably by

1 Kelly and Lidbetter. the medical witness. But, as it is known that more than one person in every 204 of the population is mentally affected, it is obvious that a considerable number of normal individuals must possess relatives who are mentally abnormal.

The personal history of an offender is of more importance than his family history. It may be impossible to assess the relative importance of inheritance and acquirement as causative factors of antisocial conduct, but it would appear that heredity may condition crime in a variable and indirect manner, not by begetting criminals, but by transmitting through the germ plasm tendencies to mental disorder and defect, temperamental instability, or faulty development of some primitive instinct antagonistic to social adjustment.

After the examination of the prisoner is complete, the medical witness should draw up his report in as simple language as possible. The symptoms indicating mental disorder or defect should be set out clearly, and facts should be distinguished from inferences. It is important that all the indications of alienation be recorded; no report can be too conclusive, for the opposing evidence may not be disclosed until the trial. The report should represent the final and considered opinion of the witness to which he should adhere, for his counsel will rely upon it, and any departure therefrom may prove misleading. If, at the last moment, fresh information requires a modification of the opinion expressed in his report, the medical witness should notify counsel before he is called into the witness box.

A witness is called upon to give evidence by replies to questions ; the opposing side is thereby given an opportunity to object to any question the answer to which is legally inadmissible. The expert witness is sometimes permitted to give his evidence in consecutive form, being questioned thereon when his statement is completed. His replies, or statement, should be as brief as 
is consistent with lucidity, so that they can be remembered and understood by the jury, who are likely to be confused by long involved expositions on a subject concerning which they have no technical experience. The use of medical terms is also to be avoided as far as possible, for the prisoner may have little education and should be able to follow the evidence in a reasonably clear manner.

The witnesses in a criminal trial may be ordered out of court until their evidence is heard in order to avoid collusion between them. The medical witness, however, is allowed to remain in court so that he can listen to the evidence and be prepared to give his opinion concerning its bearing on the state of mind of the accused.

The witness should be ready to admit his inability to answer a particular medical question; the counsel is not an expert in all branches of the law, and a witness cannot be presumed to be equally expert in all the different departments of medicine.

Embarrassing questions are sometimes put which the medical witness may have had no occasion to consider previously. For instance he may be asked by opposing counsel whether the expert on the other side is not a greater authority with wider experience than himself. The witness will not detract from his own reputation if he allows as much as possible to the opposition, but may fairly add that it would be so difficult for him to eliminate personal bias that he would prefer to leave the decision to others.

Many crimes result from love, hatred, jealousy, and other fundamental sentiments, and the witness may be asked whether the manner of their expression in a particular case is itself an indication of insanity. The simplest reply appears to be that they should so be regarded when they cause insane conduct. The jury are then left, as they should be, to decide whether the conduct in the particular case amounts to legal insanity. In this connection it is convenient to add that a medical witness should never offer $\stackrel{\mathbb{Q}}{\circ}$ his opinion that the prisoner, on whosec. behalf he appears, is irresponsible for his $\overrightarrow{\vec{*}}$ actions unless he is specifically asked the question ; for this is a matter for the jury to $\underline{\underline{G}}$ decide, and he lays himself open to reproof $\frac{\bar{\sigma}}{\sigma}$ by the judge if he assumes their function.

Occasionally, particularly in murder cases, the medical witness for the prosecution may $\vec{\circ}$ be asked by opposing counsel whether he $\vec{\omega}$ realizes the serious consequences his evidence may have for the prisoner. The correct reply was given by an expert toxicologist many years ago when he declared he was not concerned with consequences. The $\vec{\infty}$ concern of the expert is to give his evidence faithfully, the result of his evidence is the concern of others.

The witness must not allow himself to bec put in a false position, and if a question is $\stackrel{\infty}{+}$ not understood he should ask for an explar $\overrightarrow{0}$ nation before any reply is made. He shoula support his opinion by facts and reasonet. conclusions. He should speak clearly sơ that he can be heard distinctly by all concerned, and adjust the rate at which he gives his evidence by the movements of the judge's pen. And he will usually be wise to take his notes with him into the witness box to have ready for reference in case of need.

The medical witness who is unfamiliar with the work of the criminal courts is at a disadvantage in following the proceedings. It is, therefore, permissible to consider briefly a few matters concerning the practice and procedure in so far as they refer to the mental conditions of accused persons.

Crimes are classified into two main groups :-

(I) Summary offences which are dealt with at the police court or petty sessions by justices sitting without jury, and

(2) Indictable offences which admit of trial $\stackrel{\oplus}{?}$ by jury, and include treasons, felonies, and misdemeanours.

The police court is presided over by a stipendiary justice acting alone, or as at $\frac{\varrho}{2}$ 
petty sessions by two or more justices sitting together, in which case the decision is a majority and not necessarily an unanimous one. The stipendiary is a professional lawyer, but the lay justices need have no previous legal training. The usual appeal from a summary court is to quarter sessions. Prisoners are frequently remanded from courts of summary jurisdiction to enable a medical examination to be made, either in prison or whilst the prisoner is on bail, and the results of this examination are taken into account when the accused appears again in court at the expiration of the remand period. If the stipendiary or lay justices are satisfied that the accused is insane they may commit him for trial to quarter sessions or assizes if the crime be a serious one. If, however, the offence is a minor one, they can discharge him to be dealt with as a pauper lunatic under sections 15 and 20 of the Lunacy Act, 1870 , or as a private patient under the usual medical certificates. And if they are satisfied on the evidence that the offender comes within the definitions of the Mental Deficiency Act of 1927, he is usually discharged either to the care of friends, to a Poor Law institution as a "place of safety," to an institution for mental defectives, or sentence is postponed and a petition is presented to a judicial authority under the Act who can order the defective into an institution whose managers are willing to receive him (Mental Deficiency Act, I9I3, Section 8). Sometimes a short sentence of imprisonment is passed, to enable the transfer of the defective from prison to an institution willing to receive him, on the certificates of two medical men and an order from the Secretary of State (Mental Deficiency Act, I9 13, Section 9).

The procedure in courts of quarter sessions and assizes is less direct. Before the case is heard by the petty jury the witnesses for the prosecution, or so many as may be required, are heard by the grand jury consisting of at least 12 but not more than 23 members, who determine whether there is sufficient evidence to justify the defendant being placed on his trial. They are not concerned with his guilt, and the hearing is conducted in private, no counsel are present, neither are the accused or his witnesses heard. The grand jury is not concerned with the mental condition of the accused, therefore the alienist is not called upon to give evidence at this stage of the proceedings. If the grand jury consider the prosecution have not made out a sufficient case the bill of indictment is ignored and the prisoner discharged. An embarrassing situation arises sometimes when this occurs and the prisoner is insane. A suicidal melancholiac was discharged at quarter sessions beçause the grand jury were dissatisfied with the evidence that he had attempted suicide. In another case the grand jury ignored the bill, the accused being a delusional homicide who had shot a man.

When a majority of the grand jury are satisfied with the evidence against the prisoner they return "a true bill," and the case is then tried by the petty jury. But before any evidence is called the prisoner is arraigned in the presence of the petty jury. The arraignment consists of three parts, first calling the accused to the bar by name, secondly reading the indictment to him, and thirdly asking him whether he is guilty or not. The proceedings at this stage may become of immediate importance to the medical witness, for the accused may stand mute, or suffer from such disease or defect of the mind as to render him unfit to plead.

If the prisoner stands mute this may be of malice or ex visitatione Dei, and medical evidence is generally required to assist the jury to decide the issue. If mute of malice the court may order a plea of not guilty to be entered, and the trial proceeds. If the prisoner is found guilty he is sentenced in the ordinary manner. If he is mute by the will of God the court uses such means as may enable the prisoner to understand the charge and make his answer; if this cannot be done a plea of not guilty is entered, 
and has the same effect as if the person had so pleaded. Before a prisoner can be found mute of malice or mute by the will of God the jury are empanelled for the purpose, and the form of oath administered to them mentions the specific issue they are sworn to try.

A prisoner is "unfit to plead" to an indictment when, by reason of mental disease or defect, he is prevented from challenging a juror, from understanding the nature of the proceedings in court, from distinguishing between a plea of guilty or not guilty, from examining witnesses, or instructing counsel in his defence, or from following the evidence intelligently. In this event the jury are sworn by a special oath to decide the issue. If they accept the medical evidence the accused is not put on his trial ; he is said to be "insane on arraignment" and is sentenced to be detained during $\mathrm{His}$ Majesty's pleasure (Criminal Lunatics Act, I80o, Section 2). As he has not been found guilty of any offence, he can be brought up for trial if he becomes fit to plead later. It should be noted here that imbeciles and low-grade feeble-mincled aments are unfit to plead and are sentenced as insane persons, but the Secretary of State has power in such cases to transfer a defective from an asylum to an institution for defectives willing to receive him. (Section 9, Mental Deficiency Act, r9r3.)

It does not follow that because a prisoner is insane he is also unfit to plead. In many cases of melancholia and most cases of paranoia the intellect may remain sufficiently clear to fulfil the conditions required by the arraignment, and the hypomaniac and paranoiac may conduct their own defence and examine witnesses with surprising skill. The fitness or unfitness of an accused person relates to his condition at the time of trial, his mental condition at the time of the offence is immaterial at this point in the proceedings. It is essential therefore for the medical witness to examine the accused on the actual day of trial, and before he appears in court, and he must allow himself time to $\frac{2}{2}$ visit him for this purpose. Unless this is $\stackrel{c}{.}$ done the value of his evidence-that the prisoner is at that time unfit to plead-may be called into question.

Difficulty may arise when an insane

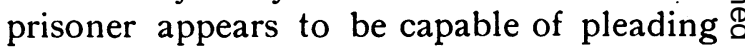
and expresses his intention to plead guilty. क In certain cases insane prisoners so plead in $\overrightarrow{0}$ order to receive a death sentence when charged with murder, or for lesser offences a sentence of imprisonment, in preference to the indeterminate sentence of detention during His Majesty's pleasure.

At other times an insane person refuses to allow a defence of insanity to be raised on $\stackrel{\infty}{v}$ his behalf, either because he regards him- 음 self as sane and considers detention in an asylum more ignominious than a sentence of imprisonment, or because he cannot $\frac{c}{9}$ appreciate that he is insane, or has done $\overrightarrow{0}$ anything wrong. The difficulty may be $\mathrm{g}$ real one in cases of murder; and when deaf. ing with cases of this kind the medicat witness should put before the jury the general evidence of insanity, and may be $\frac{\otimes}{\not}$ able to state also that in his opinion the $\stackrel{\square}{2}$ prisoner is unfit to plead as he does not $\overline{\vec{\partial}}$ appreciate the effeet of his plea, or desires to $\frac{3}{2}$ receive a sentence such as a man of sound mind would endeavour to avoid. The matter then becomes one for the jury to decide. A man of good character became 3 . depressed and suicidal, but was afraid to kill himself, and attempted to murder an entire stranger, hoping thereby to be hanged 음 and cause his own death. He struck his victim on the head with an axe bought for the purpose and followed this up by cutting o his throat with a razor. On the morning of $\mathbb{O}$ the Assize I had reason to believe that he intended to plead guilty, and as I had no: doubt he was insane I stated that he was in my opinion unfit to plead. The jury, however, did not accept this, and the prisoner on being arraigned at once pleaded guilty. In another case of murder I gave evidence of $\stackrel{\mathbb{Q}}{\mathbb{Q}}$ insanity, and supplemented this by the $\frac{\mathbb{Q}}{0}$ 
opinion that the prisoner was unfit to plead because he refused to instruct counsel fully, or speak of his delusions which had a direct bearing on the crime; his purpose being to avoid the verdict of insanity. This was not considered sufficient, and after some hesitation the accused pleaded not guilty.

The question of a prisoner's fitness to plead may also arise if he malingers insanity on entering the dock by shouting, talking nonsense, undressing himself or behaving so violently that the proceedings are interrupted. When the symptoms are assumed the trial may be held in the absence of the prisoner in cases of misdemeanour if he has already pleaded.

If an insane prisoner is fit to plead the trial proceeds in the usual way, and the prosecution call the evidence upon which they rely to connect the accused with the crime. The defence may then call evidence to rebut that of the prosecution, or call such witnesses as will support the plea that the prisoner was insane at the time of committing the crime. If the jury accept the evidence of insanity, and are satisfied that the prisoner committed the crime, they may bring in a verdict of "guilty but insane," and the accused is sentenced to be detained during His Majesty's pleasure (Trial of Lunatics Act, I883, Section 2, s.s. I and 2). Sometimes defending counsel refuse to call evidence of insanity, hoping to obtain an acquittal on the evidence, and it appears to have been consistently laid down that insanity if relied upon as a defence must be established by the defendant (Rex $v$. Smith, $6 \mathrm{Cr}$. App. Rep. 19). When however a prisoner is undefended, and declines himself to raise the issue of insanity, the practice of the Treasury Counsel is to tell the jury that the issue might be raised, and at the close of the case ask the judge whether he desires the prosecution to call any evidence they have. The judge can always raise the issue, but the prosecution have no right to do so if the defendant objects. In one case a melancholiac was charged with attempting to murder a woman and with attempted suicide. He was fit to plead, and his counsel was aware that I was prepared to give evidence that the accused was legally insane at the time of the crime. In another case a youth attempted to murder his sweetheart and then cut his own throat during a state of automatism. In both cases counsel refused to call any evidence to support a defence of insanity, and in both the judge called upon me to give evidence, and verdicts of "guilty but insane" were returned.

An insane prisoner who is unfit to plead is suffering from such a degree of insanity as to cause him to, be unfit to give evidence, and if fit to plead he is seldom called upon to give evidence unless his mental condition has recovered and there is some particular reason to call him.

At quarter sessions or assizes then two verdicts apply to insane prisoners. They may be "insane on arraignment," that is at the time of trial, or "guilty but insane" at the time the crime was committed. It is desirable that an accused person should plead whenever able to do so in order that his connection with the crime can be established by the jury. From the figures which I have already given it will be seen that in 1927 twenty-eight persons were found to be insane on arraignment and thirty-one guilty but insane.

Criticism is sometimes directed to the term "guilty but insane" as it suggests that an insane subject is convicted. The prisoner however is not found guilty of a crime, the verdict records only that he is "guilty of the act charged against him, but was insane at the time so as not to be responsible according to law."

An appeal from courts of quarter sessions or assize are determined at the Court of Criminal Appeal, which is a final court of appeal save in exceptional circumstances, when an appeal may be made from the Court of Criminal Appeal to the House of Lords. But a person who has been found insane at the trial cannot appeal, as it has 
been held that the word "conviction" does not include the finding of a jury that a person arraigned was unfit to plead ( $\operatorname{Rex} v$. Larkins 6 Cr. App. R. I94), nor does a finding that he was insane at the time of the act (Felstead v. R. 10 Cr. App. R. I 29). Moreover there is no appeal against a finding that a prisoner is fit to plead $(\operatorname{Rex} v$. Jefferson, I Cr. App. R. 95).

It sometimes happens that a prisoner who showed no indication of mental disorder at the time of the crime does so later, but recovers before his trial. In this case the trial proceeds in the usual way, and the medical man under whose care the accused was during the attack may be called upon by the defence in mitigation of sentence. If in such a case the prisoner has not recovered before trial and is fit to plead, the medical witness may be called to connect, if possible, the crime with the present attack of mental disorder.

I have already stated that a verdict is recorded that a defective is insane on arraignment if the jury find he is unfit to plead. High-grade defectives may be fit to plead, and there is no verdict " guilty but mentally defective" corresponding to the verdict "guilty but insane." The question of the mental defect of a prisoner-apart from the arraignment-is not one for the jury to decide. The chairman or recorder at quarter sessions, and the judge at assize, may call for medical evidence in support of mental deficiency after the jury have found the accused guilty. And if the offence is punishable by penal servitude or imprisonment deal with the case under Section 8 of the Mental Deficiency Act of I913, sending the prisoner to an institution for defectives willing to receive him (as may be done by courts of summary jurisdiction, see ante), provided that the court shall remit to a court of summary jurisdiction for the place where the person is committed for trial the determination of his place of residence. (Section 44, Mental Deficiency Act, I913.)

It is important to remember that if a de- fective is fit to plead and knows the nature and quality of his act, he should still be reported to the court as a case of mental deficiency, for the diagnosis of mental defect is irrespective of legal responsibility. And in undefended cases of mental disease the witness should inform the clerk of the court of the condition of the defendant, whether it falls within the restrictions of the legal definition of insanity or not.

\section{E D I T.ORIA L N EW S.}

THE recent course of M.R.C.P. lectures which were held at the Medical Society proved very successful, and the Fellowship have been asked to arrange another course in the autumn. This is being done and in addition to the lectures the course will in clude facilities for attendance at certain hospitals in order to see cases, and there wile be demonstrations of morbid specimens.

The following have promised to lecture at the course : Sir William Willcox, Dr. Langdon Brown, Dr. McNee, Dr. Hurst, Dr. Knyvett Gordon, Dr. Kinnier Wilson, Dr. Bernard Myers, Dr. de Wesselow, Dr. Parsons-Smith, Dr. L. S. T. Burrell.

The lectures will be held in the evening from October 15 to December 6 , and it is hoped that those who wish to attend will make early application to the Secretary of the Fellowship of Medicine.

\section{M.R.C.P. Special Course. \\ October I 5 to December 6, I929.}

The following lectures will be delivered at 8.30 p.m. at the Medical Society, 1 I, Chandos Street, Cavendish Square, W. I, unless otherwise indicated :-

Tuesday, October 15.-Dr. B. T. ParsonsSmith, "The Symptoms and Signs of Myocardial Failure."

Friday, October 18.-Dr. B. T. ParsonsSinith, "The Treatment of Heart Disease." 